Plasma testosterone, oestradiol and sex hormone binding globulin in Indian vegetarian women compared with Caucasian vegetarians and omnivores. Sheela Reddy, T. J. A. Key, J. W. Moore, G. M. G. Clark \& T. A. B. Sanders

Testosterone, sex hormone binding globulin, and calculated free testosterone in male vegans and omnivores. T. J. A. Key, L. S. Roe, M. Thorogood, J. I. Mann, J. W. Moore, G. M. G. Clark \& D. Wang

Methane production by ruminants and its influence on the doubly-labelled water technique. $A . J$. Midwood, $P$. Haggarty, B. A. McGaw \& J. J. Robinson

Repeated periods of dieting by women using a very low energy diet. 1. Effect on metabolic rate. Gail R. Goldberg, Susan A. Parkinson, Judith M. Savage, P. R. Murgatroyd \& A. M. Prentice

Repeated periods of dieting by women using a very low energy diet. 2. Effect on body composition. Susan $A$. Parkinson, Gail R. Goldberg, Judith M. Savage, P. R. Murgatroyd, W. A. Coward \& A. M. Prentice

Weight changes during $7 \mathrm{~d}$ weighed energy intake studies in normal men. A. C. Bruce, A. Zakary, J. Fell \& G. McNeill

Energy intake and energy expenditure in post-obese women and weight-matched controls. G. McNeill, S. G. F Bukkens, D. C. Morrison \& J. S. Smith

Resting energy expenditure in cystic fibrosis. S. A. Wootton, J. Ellis, S. Bond \& A. A. Jackson

Energy intakes and weight loss in institutionalized psychogeriatic patients. Rhoda Sutherland, J. Rucker \& S. A. Wootton

Arm circumference and energy balance in critical illness. Ceri J. Green, $T$, R. Helliwell, P. McClelland, A. A Gilbertson, R. G. Wilkes, J. M. Bone \& I. T. Campbell

Plasma noradrenaline concentrations and thermogenic responses to injected noradrenaline in the rat. A. Y. Siyamak \& I. A. Macdonald

Thermic effect of artificial sweeteners in humans: aspartame. C. A. Geissler \& D. A. James

The effect of a $3 \mathrm{~d}$ high-fat or high-carbohydrate diet on the responses to glucose ingestion in man. M. B. Sidery, I. W. Gallen \& I. A. Macdonald

Net substrate deposition in human adipose tissue in vivo after glucose ingestion and during insulin infusion. Keith N. Frayn, Simon W. Coppack \& Sandy M. Humphreys

A modified TRAP assay to measure pro-oxidant activity in serum. D. I. Thurnham \& D. Kwiatowski

Alcohol consumption and measurements of iron status. J. J. Strain, K. A. Thompson, M. E. Barker \& P. G. McKenna

Relation of plasma levels of antioxidants and cholesterol to the risk of colorectal cancer and polyps in Ireland. Kathryn R. O'Sullivan, P. M. Mathias, J. J. Strain, D. G. M. Carville, A. Tobin \& C. O'Morain

Diet and cancer of the stomach. colon, rectum, breast and lung: a prospective cohort study. P. A. van den Brandt, R. A. Goldbohm, P. van't Veer, R. J. J. Hermus \& F. Sturmans

Alzheimer's senile dementia: potential pathogenic significance of free radical and antioxidant micronutrient interactions. P. H. Evans, J. Klinowski, E. Yano \& N. Urano

Blood antioxidant status of runners in relation to training load. J. D. Robertson, G. G. Duthie, R. J. Maughan \& P. C. Morrice

Effect of dietary $\alpha$-tocopherol level on susceptibility of chicken tissues to lipid peroxidation. $P . J$. A. Sheehy, P. A. Morrissey \& A. Flynn

Vitamin E alters T cell subsets in elderly patients. L. Purkins, N. D. Penn, J. Kelleher \& R. V. Heatley

Immune function in vitamin E-deficient rats. L. Purkins, J. Kelleher \& R. V. Heatley

Gastric juice ascorbic acid: effects of disease, hypochlorhydria and stimulation of gastric secretion. C. J. Schorah, J. N. Primrose, G. M. Sobala, M. J. Sanderson \& M. Rogers

Selenium depletion and repletion: effects on the thyroid gland in the rat. J. R. Arthur, F. Nicol, P.W. H. Rae \& G. J. Beckett

Nitrosation of amino acids and peptides in gastric contents. Douglas S. Annan, Brian C. Challis, John D. Harrison, Jim Iley, David L. Morris \& Gillian E. Shears

Human milk: a source of potentially toxic and carcinogenic halosubstituted biphenyls. J. T. Borlakoglu. N. J. Borlak \& R. R. Dils

Arginine in benign and malignant disease of the breast and colon. K. G. M. Park, S. D. Heys, C. I. Harris, M. A. McNurlan, R. J. Steele, O. Eremin \& P.J. Garlick

Do rates of protein synthesis differ in separate biopsies from the same tumour? S. D. Heys, K. G. M. Park, M. A. McNurlan, K. Blessing, O. Eremin \& P. J. Garlick

Effect of the intestinal microflora and dietary fibre on colonic epithelial cell proliferation. R. A. Goodlad, B. Ratcliffe, J. P. Fordham, C. Y. Lee \& N. A. Wright

Stimulation of large bowel fermentation has no effects on duodenal epithelial proliferation in rats given white bread-based diets. J. C. Mathers, Devina McClean \& Fiona B. Key

Oats, gastrointestinal cell proliferation and serum cholesterol in the rat. E. K. Lund \& I.T. Johnson

Lipogenesis measured in vivo in tumour-bearing rats. $O$. Obeid \& $P, W$. Emery

Smoking and diet: is the diet of smokers different? Janet Cade \& Barrie Margetts

Comparison of the diets of smokers and non-smokers. Margaret J. Whichelow \& Sharon W. Erzinglioglu

What YOU think causes obesity. G. P. Webb \& C. A. Geissler

Effects of dietary supplementation on work performance in Gambian labourers. E. Daiz, G. R. Goldberg. M. Taylor, J. M. Savage, D. Sellen, W. A. Coward \& A. Prentice

Activity and energy expenditure of lactating women in rural Ghana. Margaret A. Armar-Klemesu \& Erica F Wheeler

Rationing and wartime food policies in Iran. F. Rabiee \& C. A. Geissler

The effects of yeast culture on yeast numbers and fermentation in the rumen of sheep. C. J. Newbold, P. E. V. Williams, N. McKain, A. Walker \& R. J. Wallace

Protein digestibility measured by ${ }^{15} \mathrm{~N}$ and homoarginine. N. Roos, H. Hagemeister \& J. Scholtissek

The movement of intact urea across the mucosa of the defunctioned human colon. B. J. Moran, S. J. Karran \& A. A. Jackson

Hypocholesterolaemic and other reponses to oat bran intake in humans. R. W. Welch, A. M. McVeigh \& C. Murphy

Large bowel fermentation in rats given raw peas in the diet. Laurentina M. R. Pedroso, J. C. Mathers \& Heather J. Finlayson

$10 \mathrm{~A}$

$11 \mathrm{~A}$

$14 \mathrm{~A}$

$15 \mathrm{~A}$

$16 \mathrm{~A}$

18A

$19 \mathrm{~A}$

$21 \mathrm{~A}$

$22 \mathrm{~A}$

$23 \mathrm{~A}$

26A

$27 \mathrm{~A}$

28A

$29 \mathrm{~A}$

$30 \mathrm{~A}$

$31 \mathrm{~A}$

$32 \mathrm{~A}$

$33 \mathrm{~A}$

$34 \mathrm{~A}$

$35 \mathrm{~A}$

$36 \mathrm{~A}$

$37 \mathrm{~A}$

$38 \mathrm{~A}$

$39 \mathrm{~A}$

$40 \mathrm{~A}$

$41 \mathrm{~A}$

$42 \mathrm{~A}$

$43 \mathrm{~A}$

$44 \mathrm{~A}$

$45 \mathrm{~A}$

$46 \mathrm{~A}$

$47 \mathrm{~A}$

$48 \mathrm{~A}$

49A

$50 \mathrm{~A}$

$51 \mathrm{~A}$ 


\title{
of the Nutrition
}

\section{Society}

VOL. 49 No. 1 FEBRUARY 1990

\section{CONTENTS}

\section{WORKSHOP}

One Hundred and Eightieth Scottish Meeting

Kelvin Conference Centre, Glasgow

18 NOVEMBER 1988

NUTRITION AND FOOD PROCESSING

Chairman: D. PARRY, Queen Margaret College, Edinburgh

Food preservatives and the microbiological consequences of their reduction or omission. T. A. Roberts \& P.J. McClure

Nutritional recommendations for $n-3$ polyunsaturated fatty acids and the challenge to the food industry. S. M. Barlow, F. V. K. Young \& I. F. Duthie

Implications of nutritional recommendations on sugar for product development. $N$. J. Jardine, $D$. G. Edwards \& C. McMenemy

Fibre sources for the food industry. I. T. Johnson

Food fortification. D. P. Richardson

\section{SYMPOSIUM PROCEEDINGS}

\author{
Liverpool Medical Institution, Liverpool \\ 6/7 APRIL 1989 \\ INTRACELLULAR CALCIUM IN THE CONTROL OF METABOLISM \\ Chairmen: P. COBBOLD, University of Liverpool \\ R. H. T. EDWARDS, University of Liverpool \\ G. A. J. PITT, University of Liverpool
}

Calcium as an intracellular regulator. Anthony K. Campbell

Intracellular calcium ions and intramitochondrial $\mathrm{Ca}^{2+}$ in the regulation of energy metabolism in mammalian tissues. James G. McCormack \& Richard M. Denton

Intracellular calcium, cell injury and relationships to free radicals and fatty acid metabolism. M. J. Jackson

Intra- and extracellular calcium and hypertension. Anthony $M$. Heagerty

Vitamin D and other extracellular factors in the control of growth. Isobel P. Braidman

\section{ABSTRACTS OF COMMUNICATIONS}

\author{
Lady Spencer-Churchill College, Oxford Polytechnic, Oxford \\ 26-28 JULY 1989
}

The nutrition and environment of the early human embryo. A. L. Gott, K. Hardy, R. M. L. Winston \& H. J. Leese

Differential effects of dietary fatty acid saturation and chain length on lipogenesis in liver and mammary gland of lactating rats. Paulo F. A. Souza \& Dermot H. Williamson

Breast-milk calcium and phosphorus concentrations of British and Gambian mothers during prolonged lactation. Ann Prentice, M. A. Laskey, B. Dibba \& J. Shaw

Background variations in breath carbon-13 enrichment in free-living infants and toddlers. Odite Dewitt, $P . R$. Murgatroyd, Ann Prentice \& W. A. Coward

The urinary excretion of 5-oxoproline in healthy term infants. C. Persaud, N. Evans, N. Rutter, M. Hall, S. Smith \& A. A.. Jackson

The effects of gonadectomy on weight gain and corticosterone metabolism in rats. C. J. H. Woodward, G. R. Hervey, R. E. Oakey \& E. M. Whitaker

[Continued on p. iii of wrapper]

(C) The Nutrition Society, 1990

\section{CAMBRIDGE UNIVERSITY PRESS}

The Pitt Building. Trumpington Street, Cambridge CB2 1RP

40 West 20th Street, New York, NY 10011, USA

10 Stamford Road. Oakleigh, Melbourme 3166, Australia 